\title{
Investigations on the Genetics of Resistance to Root-knot Nematodes (Meloidogyne incognita) in Tobacco (Nicotiana tabacum)*
}

\author{
by \\ Rahim Honarnejad ${ }^{1}$ and $M$ Shoai Deylami ${ }^{2}$ \\ ${ }^{1}$ College of Agricultural Sciences, Guilan University, Rasht, Iran. \\ ${ }^{2}$ Tobacco Research Center, Rasht, Iran.
}

\section{SUMMARY}

The analysis of a full diallel cross of ten tobacco varieties showed that genetic control of resistance to root-knot nematodes (Meloidogyne incognita) in tobacco was governed by partial dominance. When measuring the overall genetic variance, the portion of additive variance was found to be very substantial. This property may well be inherited by progenies and with a high degree of heritability $(0.60-0.63)$.

Partitioning the total sums of squares of the genotypes into the sum of squares for general (GCA) and specific combining ability (SCA) of parents and hybrids points to additive and non-additive gene activities in generating resistance to root-knot nematodes in tobacco. Because of significant reciprocal differences, the maternal cytoplasm plays an important role in the inheritance of resistance to root-knot nematodes. The proportion of additive and heritable variance was significant and to such an extent $(60 \%)$ that a selection for resistant lines might be a promising project. Since some varieties show a high GCA for resistance, they could be regarded as donors for resistance for progenies. In addition, the significantly high SCA and resistance of several hybrids would suggest successful selection of lines with resistance to root-knot nematodes in tobacco. [Beitr. Tabakforsch. Int. 19 (2000) 17-23]

\section{ZUSAMMENFASSUNG}

Die Analyse einer vollständigen Diallelkreuzung von zehn Tabaksorten zeigte, dass die genetische Kontrolle der Resistenz gegen Wurzelknollennematoden (Meloidogyne incognita) bei der Tabakpflanze eine partielle Dominanz aufwies. Die Untersuchung der allgemeinen genetischen Varianz offenbarte die substantielle Bedeutung der additiven Varianz. Diese Eigenschaft könnte gut mit einem hohen Grad an Heritabilität auf die Nachkommenschaft weitervererbt werden $(0,60-0,63)$.

Die Aufteilung der gesamten Quadratsummen der Genotypen in die Quadratsumme für die generelle (GCA [general combining ability]) und die spezifische Fähigkeit zur Kombination (SCA [specific combining ability]) von Eltern und Hybriden weist auf additive und nicht additive Genwirkungen bei der Ausprägung der Resistenz gegen Wurzelknollennematoden bei Tabak hin. Wegen signifikanter reziproker Unterschiede spielt das mütterliche Zellplasma eine bedeutende Rolle bei der Vererbung der Resistenz gegen Wurzelknollennematoden. Das Verhältnis additiver und erblicher Varianz war signifikant und zwar in einem solchen Ausmaß (60\%), dass die Selektion auf resistente Zuchtlinien ein vielversprechendes Vorhaben sein könnte. Da einige Varietäten eine hohe GCA für Resistenz aufweisen, könnten sie als Vererber der Resistenz auf die Nachkommenschaft betrachtet werden. Außerdem 
könnte die signifikant hohe SCA und die Resistenz mehrerer Hybride die erfolgreiche Selektion von Zuchtlinien mit Resistenz gegen Wurzelknollennematoden bei Tabak vermuten lassen. [Beitr. Tabakforsch. Int. 19 (2000) 17-23]

\section{RESUME}

L'analyse de croisements dialléliques de dix cultivars de tabac a révélé que le mécanisme génétique de la résistance aux nématodes Meloidogyne incognita chez le tabac est gouverné par des gènes partiellement dominants. L'examen de la variabilité génétique globale a montré que la part des effets additifs des gènes était substantielle. Cette propriété pourrait être transmise héréditairement aux descendances avec un haut degré d'héritabilité $(0,60-0,63)$.

$\mathrm{La}$ répartition des sommes des carrés totales des génotypes entre la somme des carrés des génotypes avec une valeur hybride générale (GCA) et celles avec une valeur hybride spécifique (SCA) chez les parents et les hybrides indique des effets additifs et non - additifs des gènes dans le contrôle génétique de la résistance aux nématodes. En raison de différences réciproques significatives le cytoplasme maternel joue un rôle important dans la transmission héréditaire de la résistance aux nématodes. La relation entre les effets additifs et héréditaires est significative et avec une héritabilité de $60 \%$ la sélection des lignées résistantes aux nématodes paraît prometteuse. Puisque certaines variétés ont une valeur hybride générale significative, elles pourraient avoir fourni la base génétique de la transmission héréditaire de la résistance aux nématodes. Aussi, en raison de la valeur hybride spécifique significative et la résistance aux nématodes de certains hybrides, la sélection génétique pour la résistance aux nématodes chez le tabac parait prometteuse. [Beitr. Tabakforsch. Int. 19 (2000) 17-23]

\section{INTRODUCTION}

Nematodes are plant parasites, 300 to $1000 \mu \mathrm{m}$ (up to $4 \mathrm{~mm}$ ) in length. Crop plants infested with root-knot nematodes generally respond by forming galls on the roots. In Iran, root-knot nematodes cause substantial damage to tobacco every year. Chemical control using insecticides or nematacides, is only appropriate for small fields, but would be detrimental to the environment and not economic if applied to large fields. PULLEN et al. (12) demonstrated the effect of Fosthiazat on tobacco root-knot nematodes. Following application of this nematacide in spring or fall they observed a reduction in damage and an increase in crop productivity. Crop rotation combined with nematacide application led to a decrease in the nematode population and an increase in crop productivity (5).
The mode of inheritance for resistance to tobacco nematodes has rarely been investigated. DAVIES et al. (3) showed that lines of group I tobacco (Nicotiana repanda, $N$. longiflora $\times N$. tabacum) had fewer galls on roots and only small populations of nematodes when compared with variety NC 2326, which is less resistant. Lines of group II ( $N$. repanda $\times N$. tabacum) proved to be susceptible and only those of $N$. repanda displayed significant resistance. RICH et al. (13) reported damage caused by root-knot nematodes in tobacco fields in Florida, USA. According to their observations Meloidogyne javanica occurred in $65 \%$ of the fields, $M$. incognita in $33 \%$ of the fields, and M. arenaria in only one field. In $57 \%$ of the fields damage was judged to be fair to heavy, and $M$. javanica was identified as the parasite.

Practical and economically feasible methods for reducing root-knot nematodes would be by the use of existing resistant tobacco varieties, or by transferring resistance to elite or high-performance lines. However, the production of resistant varieties without knowing (a) the mode of inheritance of the resistance genes, (b) their combining ability, and (c) the heritability of resistance factors in tobacco would appear to be difficult. Key information of this kind is usually provided to the breeder by appropriate quantitative genetic investigations. Diallel crosses as presented by JINKS and HAYMAN $(11)$, HAYMAN $(9,10)$ and GRIFFING $(7,8)$ can be applied to obtain this type of information on all kinds of crop plants $(1,2,6)$.

\section{MATERIAL AND METHODS}

In 1993, 10 Virginia tobacco varieties (Nicotiana tabacum L.) were crossed in a full diallel and planted in the experimental field of the Tobacco Research Center in Rasht, Northern Iran. The parents were as follows:
1: Virginia $\mathrm{E}_{1}$
6: R 30
2: $\quad$ Coker 347
7: $\quad$ Coker 411
3: Coker 319
8: $\quad$ Speight G-28
4: Coker 258
9: $\mathrm{N}_{2}$
5: McNair 944 10: Perega

The $\mathrm{F}_{1}$ progeny was planted in 1994 in a randomized block design with four replicates. At the end of the growing period the degree of nematode infestation of the roots was scored based on the number and size of the galls. Grade 1 indicated lowest to Grade 5 the heaviest infestation. Five plants were taken from each row, scored for infestation, and the mean calculated. Data for the 10 parents and 90 hybrids were subjected to analysis of variance and based on the significance of the F-test for all genotypes, a diallel analysis was performed according to the method published by GRIFFING (8) and SINGH et al. (14).

The total sums of squares of genotypes were partitioned into two components, i.e. GCA and SCA. The GCA was determined for each variety, the SCA for all progeny. A $t$-distribution was used to test the signifi- 
cance for GCA and SCA. The calculation of additive variance was based on the GCA, that for dominance on SCA. The variance component was used to give an estimate of the heritability of resistance in tobacco varieties to root-knot nematodes according to methods by HAYMAN $(9,10)$ and by SINGH et al. (14). Detailed information on gene effects and distribution of resistance genes among parents was obtained via regression methods of HAYMAN $(9,10)$ and SINGH et. al. (14).

\section{RESULTS AND DISCUSSION}

Table 1 shows the results of the analysis of diallel for 100 genotypes (10 parents and 90 hybrids). There were substantial differences in root-knot nematode resistance between the genotypes. The significant GCA and SCA showed additive and non-additive gene effects in the genetic control of resistance to root-knot nematodes, but the portion of additive gene effects in genetic variance was higher. Because of significant reciprocal differences, the maternal cytoplasm has an important role in the inheritance of resistance to root-knot nematodes. Table 2 presents the average infestation of 10 parents and 90 hybrids. Variety \# 1 (Virginia $\mathrm{E}_{1}$ ), the most widely cultivated variety in the Province of Guilan, was rather vulnerable to root-knot nematodes and had an average infestation score of 4.25. This variety was used as the standard for comparing the other varieties. Varieties Coker 347, Coker 258, R 30 , Speight $\mathrm{G}-28$ and $\mathrm{N}_{2}$ had the most dominant alleles for root-knot nematode resistance (Figure 1) and were significantly more resistant than the standard variety Virginia $E_{1}$. Varieties Coker 319, McNair 944, and Perega, on the other hand, had recessive alleles for resistance to nematodes and had similar infestation scores to the standard variety.

The degree of nematode resistance or susceptibility of the parents was examined using the family means of the progeny. This character appears to have a relatively high degree of heritability. Progeny from a cross between variety Coker 347 with other varieties for instance, showed significantly less infestation than the standard variety Virginia $E_{1}$. A similar result was found for progeny derived from crosses with varieties Coker 258 and $\mathrm{R} 30$. The results of the experiment suggested that crosses between resistant varieties produced progeny with relatively high resistance to nematodes. Based on the significance of the F-test (Table 1), the diallel was analysed and the results shown as the graph of covariance of the parent-progeny array plotted against the array variances according to JINKS and HAYMAN (11) and HAYMAN (10) as shown in Figure 1. There was no evidence of non-allelic interaction since the regression coefficient $(b=1.0 \pm 0.09)$ of the array variance $(V r)$ against the array of parent-progeny covariance $(W r)$ did not differ significantly from unity. It was assumed that in this investigation the conditions required by HAYMAN (10) were completely fulfilled. The regression line on the $W r$ ordinate was positive (Figure 1) which suggested that there was partial dominance in the genetic control of resistance to root-knot nematodes ( $D$ [component of variation due to additive effect of the genes] $=1.920>H_{1}$ [component of variation due to the dominance effect of the genes $]=0.918)$. The portion of additive and heritable variance in the overall genetic variance was relatively high, one may therefore expect that this character would be inherited by the progeny.

The spread of parents along the regression line reveals information regarding the distribution of dominant and recessive alleles for resistance to root-knot nematodes in tobacco varieties. Varieties Coker 347, Coker 258, R 30, Speight G-28 and $\mathrm{N}_{2}$ for example were positioned close to the origin and had most of the dominant alleles for resistance, while varieties Virginia $\mathrm{E}_{1}$, Coker 319, McNair 944, Coker 411 and Perega had most of the recessive alleles for resistance and were

Table 1.

Analysis of variance (ANOVA) of diallel crosses from 10 tobacco cultivars and 90 progenies for resistance to Meloidogyne incognita.

\begin{tabular}{lccc}
\hline Source of variance & Degree of freedom (D.F.) & Sum of squares (S.S.) & Mean square (M.S.) \\
\hline Total & 399 & 585.61 & - \\
Genotypes & 99 & 396.17 & $4.002^{\star *}$ \\
GCA & 9 & 241.06 & $26.784^{* *}$ \\
SCA & 45 & 108.90 & $2.420^{\star *}$ \\
Reciprocal & 45 & 46.22 & $1.027^{* *}$ \\
Blocks & 3 & 12.35 & - \\
Error & 297 & 177.09 & 0.596 \\
\hline
\end{tabular}

\footnotetext{
**: Significant at $1 \%$ level, respectively.
} 


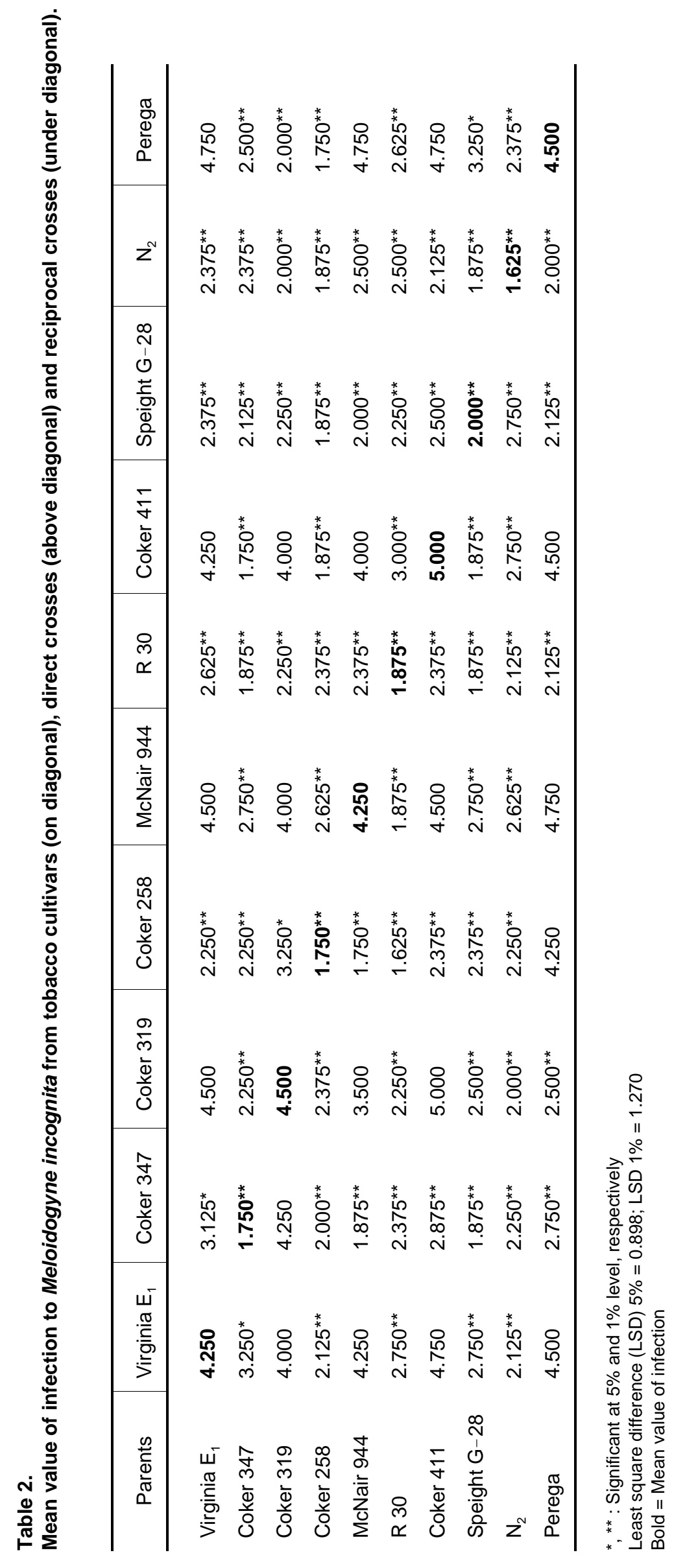




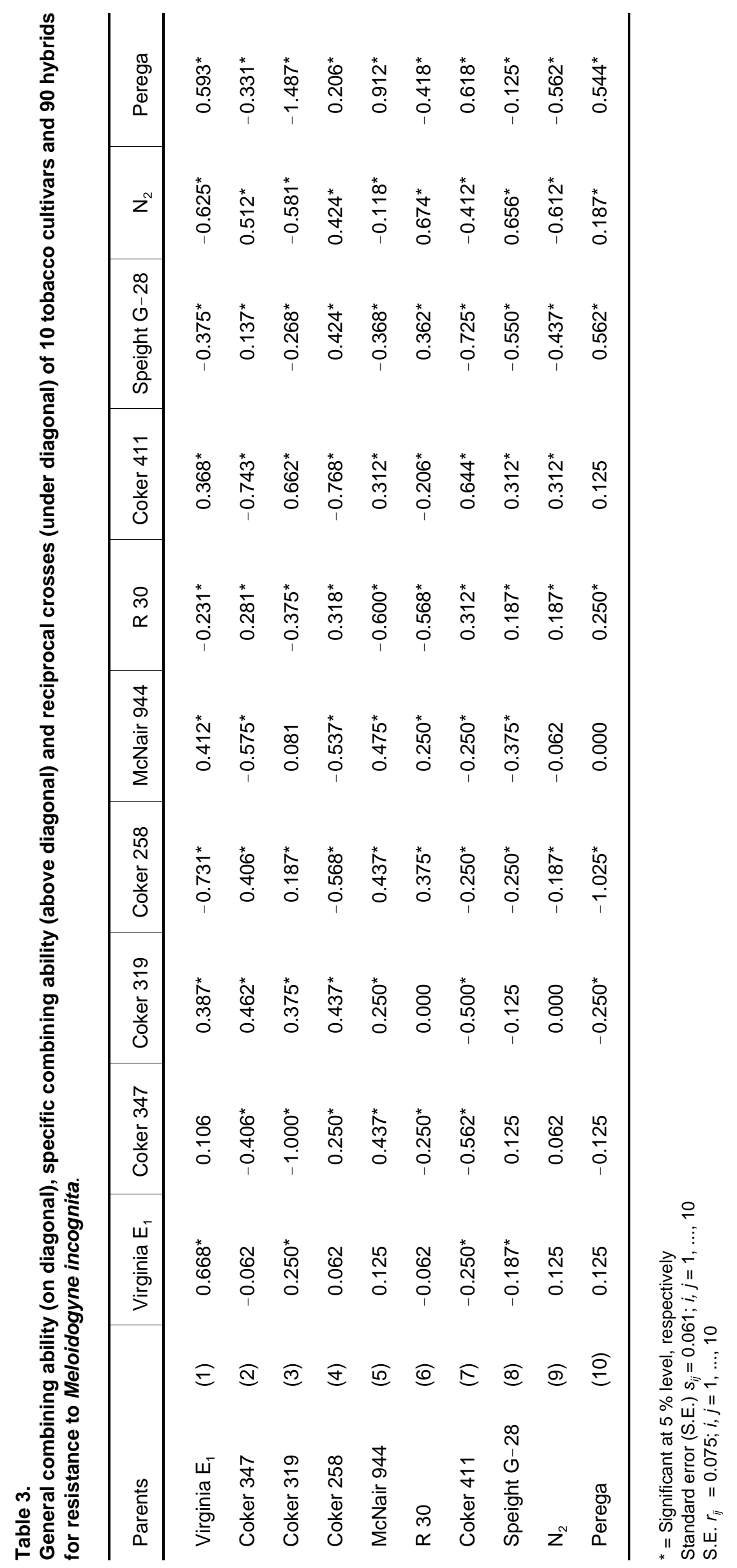




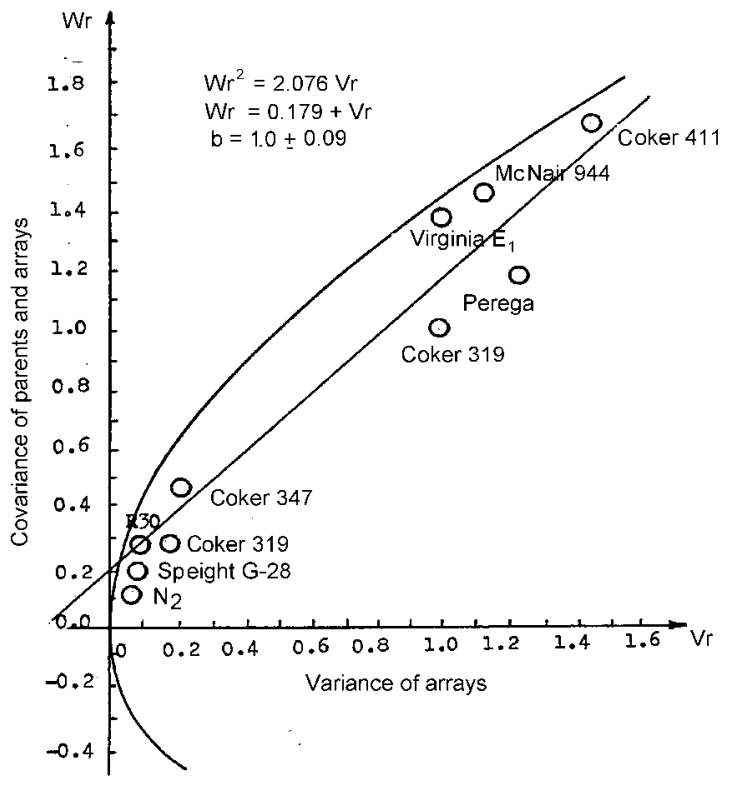

Figure 1.

Regression line $W r, V r$ and the limiting parabola $W r^{2}$ with distribution of parents for resistance to root knot nematodes (Meloidogyne incognita).

rather susceptible to infestation. This is shown in Table 2 where the variety Coker 411 with most of the recessive alleles for resistance (Figure 1) was also the most susceptible. The spread varieties along the regression line demonstrates that in tobacco, resistance to root-knot nematodes is mainly controlled by the dominant and susceptibility by recessive alleles.

Following these investigations, the difference between $H_{1}$ and $H_{2}$ was rather small $(0.03) ; H_{2}=H_{1}\left[1-(u-v)^{2}\right]$, where $u=$ proportion of positive genes in the parents, $v=$ proportion of negative genes in the parents. Furthermore, $\mathrm{H}_{2} / 4 \mathrm{H}_{1}$ or the average multiplication product of the relative occurrence of dominant and recessive alleles in parents, is 0.24 . This value is approaching the maximum of 0.25 . The narrow sense heritability of 0.63 suggests a relatively high portion of additive variance in relation to the overall variance. Accordingly, a selection of varieties with resistance to root-knot nematodes may be feasible.

The analysis of variance (Table 1) with the total sums of squares of the genotypes partitioned into the GCA and SCA showed that these two components had significant $F$-tests. This suggests that both additive and non-additive gene activities participate in the control of resistance.

The GCA was calculated for each parent and the SCA for the progeny (Table 3). The GCA of the parents for resistance to root-knot nematodes (on the diagonal in Table 3) indicated that varieties Coker 347, Coker 258, R 30, Speight G-28, and $\mathrm{N}_{2}$ had most of the dominant alleles for resistance (Figure 1), were the least infested and also had (Table 2) the highest GCA.
The positive correlation $(r=0.98)$ between GCA of the varieties and their susceptibility reveals a close relationship between these two parameters. Based on the additive variance $\left(\sigma_{A}^{2}=2.44\right)$, dominance variance $\left(\sigma_{D}^{2}=1.0\right)$, variance of error $\left(\sigma_{e}^{2}=0.60\right)$, and variance of phenotype $\left(\sigma_{P}^{2}=4.04\right)$, the heritability of resistance of genotypes has been estimated $\left(b^{2}=0.60\right)$. As a consequence, a successful selection of resistant lines should be possible.

Table 3 demonstrated that hybrids derived from crosses with at least one parent showing dominant alleles for resistance produced significantly higher SCA. This was true for Virginia $\mathrm{E}_{1} \times$ Coker 258, Coker $258 \times$ Coker 411, McNair $944 \times$ Speight G-28, and Coker $411 \times$ $\mathrm{N}_{2}$. These hybrids also showed the least infestation with nematodes. The progeny from parents Virginia $\mathrm{E}_{1}$, Coker 319, McNair 944, Coker 411 and Perega with a positive GCA, were generally susceptible to nematodes. Exceptions did occur, as in Coker $258 \times \mathrm{R} 30$, and Coker $319 \times$ Perega. The data in Table 3 therefore did not reveal a clear-cut picture of resistance of the genotypes.

The evidence from this study would indicate that, based on the significant SCA of various hybrids and significant heritability of resistance in the progeny, a substantial gain in selecting for nematode resistance can be realized. It may also point to the selection of desirable progeny through application of the pedigree method.

\section{REFERENCES}

1. Amarnath, S.: Combining ability analysis for stomatal density in chewing tobacco (Nicotiana tabacum L.); Tob. Res. 17 (1991) 127-128.

2. Chen, S.Y.: Genetic studies of leaf yield and nicotine content in Nicotiana tabacum L; Taiwan Agricult. Q. 8 (1972) 124-132.

3. Davis, E.L., J.R. Rich and G.R. Gwynn: Reaction of selected Nicotiana spp. $\times$ Nicotiana tabacum crosses grown in microplots to 3 Meloidogyne spp; Nematropica 18 (1988) 109-116.

4. Fortnum, B.A., D.T. Gooden, R.E. Currin, and S.B. Martin: Spring and fall fumigation for control of Meloidogyne spp. on tobacco; J. Nematol. 22 (1990) 645-650.

5. Fortnum, B.A., and R.E. Durrin: Crop rotation and nematacide effects on the frequency of Meloidogyne spp. in a mixed population; Phytopathology 83 (1993) 350-355.

6. Ghaderi, A., B. Ehdai, and E.H. Everson: A diallel analysis of height in wheat (Triticum aestivum); Iran. J. Agric. Sci. 2 (1973) 51-55.

7. Griffing, B.: A generalized treatment of the use of diallel crosses in quantitative inheritance; Heredity 10 (1956) 31-50. 
8. Griffing, B.: Concept of general and specific combining ability in relation to diallel crossing system; Aust. J. Biol. Sci. 9 (1956) 463-493.

9. Hayman, B.I.: The analysis of variance of diallel tables; Biometrics 10 (1954) 235-244.

10. Hayman, B.I.: The theory and analysis of diallel crosses; Genetics 39 (1954) 789-809.

11. Jinks, J.H., and B.I. Hayman: The analysis of diallel crosses; Maize Genet. Coop. Newsl. 28 (1953) 48-54.

12. Pullen, M.P., and B.A. Fortnum: Effects of Forsthiazate on Meloidogyne spp. and yield of flue-cured tobacco; J. Nematol. 26 (1994) 116-123.

13. Rich, J.R., and M.R. Garcia: Nature of the root-knot disease in Florida, USA tobacco; Plant Dis. 69 (1985) 972-974.
14. Singh, R.K. and B.D. Chaudhary: Biometrical methods in quantitative genetics analysis; Kalyani Publ., Ludhiana, New Delhi, 1977.

Acknowledgement: The authors wish to thank one of the referees who, in addition to valuable comments, took great effort in correcting the first draft of the manuscript in grammar and style.

Address for correspondence:

College of Agricultural Sciences

Guilan University

P.O. Box 3179

Rasht, Iran. 